\title{
Perceptions on Motivating Factors and Future Prospects of Green Construction in Oman
}

\author{
Nazirah Zainul Abidin ${ }^{1} \&$ Ayishatul Powmya ${ }^{2}$ \\ ${ }^{1}$ School of Housing, Building and Planning, Universiti Sains Malaysia, Malaysia \\ ${ }^{2}$ Muscat College, Sultanate of Oman \\ Correspondence: Nazirah Zainul Abidin, School of Housing, Building and Planning, Universiti Sains Malaysia, \\ 11800 Pulau Pinang, Malaysia. Tel: 60-4-653-3183. E-mail: nazirah_za@usm.my
}

Received: May 27, 2014 Accepted: June 4, 2014 Online Published: September 24, 2014

doi:10.5539/jsd.v7n5p231 URL: http://dx.doi.org/10.5539/jsd.v7n5p231

\begin{abstract}
The pressure of modernization and urbanization stimulated positive growth in Oman's construction industry especially in infrastructure development. The slower pace of construction progress in the past provides huge opportunity for the green concept to be integrated in tandem with the country's growth. The lack of evidence on green construction progress in Oman suggests that this concept is not yet at the forefront of the construction industry agenda. Proactive actions from the government, private companies and professional bodies are crucial to bring 'greener' change to the industry. Through surveys, this paper discusses the drivers to motivate construction practitioners to participate in implementing green concept into their construction projects and explore the perceptions of these practitioners on the future outlook of green concept in Oman. The motivating factors are categorized into 4: finance, knowledge and awareness, business strategy and ethics. The future scenario can be seen from two perspectives: promising outlook and status quo. This study sheds light on the status of green construction in Oman to enable further recommendations be made to improve and promote wider application in the future.
\end{abstract}

Keywords: construction barriers, green concept, Oman construction industry, sustainable building, survey

\section{Introduction}

The Middle East Region's main problems are water shortage and high temperatures during summer. Many argued that these conditions create unique set of difficulties in incorporating green elements in construction projects (Al Saleh \& Taleb, 2010; Alnaser \& Flanagan, 2007). Blessed with huge oil reserves, little attention is thus given to the need to save energy. Middle Eastern countries are at the top of the list of largest per capita ecological footprint, with Qatar being the highest at 44 metric tons per person annually (Katkhuda, 2013). The booming construction sector has resulted in escalation of domestic energy consumption per capita, (Al Hathloul, 2004) putting these countries as among the highest contributor to $\mathrm{CO}^{2}$ emission per capita (Carbon Dioxide Information Analysis Centre, 2007). Going green is the way forward for the industry's long term sustainability. For example, Al-Badi, Malik and Gastli (2011) projected power demand in Oman to grow from 3613MW in 2010 to 6043 MW by 2016, an average increase of around $8.5 \%$ per year. As such, Oman has launched 6 pilot renewable energy projects to harness renewable energy resources and reduce dependency of its oil and gas.

While its neighboring countries such as U.A.E. and Qatar are fast developing, the Sultanate of Oman took a slower pace and focused their attention on improving the internal affairs of the country, such as education and quality of living. Oman has seen stable growth in terms of health, education and income in the last 40 years (United Nation Development Programme [UNDP], 2010). Oman also realized the need to improve its infrastructures and buildings, with the government investing continuously in developing infrastructure all over the Sultanate. In the last five years, the country has seen rapid movement in the construction sector. Nonetheless, it is believed that Oman has been left behind on green development movement because unlike other countries that experienced pollution problems and rise in energy costs, Oman continues to enjoy cheap energy and is well acclimatized to arid weather. According to Al-Badi et al. (2011), Oman can catch up with the rest of the world because it has adequate intellectual and financial resources to do so.

Green construction offers an opportunity to leave a lighter footprint on the environment through numerous 
benefits to society and their surroundings besides providing a sound business case. It is commonly associated with the use of green technology especially to reduce energy consumption, indoor cooling, water saving, green materials etc. There are many terminologies used to describe green construction such as sustainable construction, eco-friendly concept, environmentally-responsible design, energy-efficient approach and others. Bringing change to the construction industry such as pushing for green construction requires numerous efforts from many stakeholders and the transition from conventional to green approach will invariably consume time (Zainul Abidin \& Powmya, 2013). The concept of green construction, although lauded by many countries, is still in its infancy to Gulf Cooperation Council (GCC) countries. However, the Middle Eastern region has made great progress in recent years with more designers pursuing green design (Katkhuda, 2013). The current construction progress in Oman provides huge opportunity for the green concept to be integrated in tandem with the country's growth. Economically booming Oman has many new projects in store. As such, it is pertinent to push the green concept diligently into the construction industry to optimize the opportunity of building green for these new projects.

This paper discusses the current progress of green construction in Oman. A survey has been conducted to explore the motivational factors in pursuing green construction and a 5-year future outlook as perceived by the construction practitioners. The findings suggest that more efforts are necessary to push green construction to the forefront and the government, with collaborative effort from professional bodies, should play the major role in this development.

\section{Green Progress in Oman}

The Sultanate of Oman is experiencing economic growth thanks to backing from oil-fueled state coffers. The construction and infrastructure sectors had a growth of $11.9 \%$ in 2012 and further growth of $8.4 \%$ in 2013 (Business Monitor International, 2013). The Government of Oman is focusing on large-scale infrastructure projects and the development of industrial capacity in line with its 'Oman Vision 2020'. Some of the ongoing or planned key infrastructure projects in Oman are International Railway Project, Al-Madina A'Zarqa (Blue City), Muscat International Airport, The Wave Muscat, Duqm Development Project, Sohar Industrial Port and Oman Convention and Exhibition Centre (Business Monitor International, 2013). The government has also increased spending for the construction sector in 2012 by $23 \%$ over the corresponding figure for 2011 . The allocation for the housing sector surged $21.5 \%$ from RO266 million in 2011 to RO323 million in 2012, including the allocation of housing units for low income citizens (Albawaba Business, 2012). In the Eighth Five-Year Plan (2011 - 2015), US\$ 6.5 billion a year has been allocated for investment projects, US\$ 1.2 billion for housing, US\$ 4.2 billion for airport expansion and construction, US\$ 3.1 billion for road projects, US\$ 1.3 billion for seaports and US\$ 1.2 billion for the utilities sector (Oxford Business Group, 2012).

Excessive development without proper attention to environmental needs will lead to irreversible impact to the environment and its surrounding (Ling \& Gunawansa, 2011; Zainul Abidin, 2010). As Oman is still in the early stages of the construction boom, the negative impacts of unsustainable construction may not yet be apparent but continued ignorance to the importance of being green, will inevitably see it suffer the same ill-fated problems faced by many countries. Currently, Oman faces water scarcity and periodic droughts (Bertelsmann Transformation Index [BTI], 2012). Due to geophysical and climatic setting of the country, $75 \%$ of the country's total surface is covered by desert, which leaves $25 \%$ remaining land to be shared for different purposes of the Omani society. While land consumption for residential, services and transport infrastructure are increasing steadily, suitable land for agriculture is decreasing. This supports rural-to-urban migration or transition and thus creates new demands on shrinking land resources. Urban settlement patterns are created through random additional of freestanding villas on walled plots, consuming high amount of energy for air-conditioning (Nebel, 2013). The residential sector is the largest consumer category with its consumption taking more than half of the total system energy (67\%) in 2011 (Authority for Electricity Regulation, 2011). Buildings are usually designed by engineers, creating design stereotypes, poor design quality and lack of design ingenuity normally found in architecturally-designed buildings (Zainul Abidin \& Powmya, 2013). Oman's economy is heavily dependent on the oil and gas sectors. However, Omani oil fields are generally smaller, more widely scattered and have higher production costs than other Arabian Gulf countries. The annual demand curve for energy reflects the climate in Oman and is highly seasonal. The average summer demand is more than double of the average winter demand. The future energy demands in Oman are expected to rise due to increases in population, expansion of new industries and more tourism projects which will require substantial power needs (Al-Badi et al., 2011). As Oman experienced little rainfall in the past, attention was not given to drainage systems, but the change of climate in the last 3 years has seen more frequent rainfall which leads to scattered flooding due to the absence or poor drainage system.

Oman has sound environmental law, enforced by the Ministry of Environment and Climate Affairs. Energy 
conservation and developing renewable energy, along with preserving the environment, are among the priorities of Oman's Eight Five-Year Development Plan (2011 - 2015) (The Research Council, 2013). Research and development (R\&D) was not given much attention in the past with R\&D evaluated at $0.1 \%$ of GDP in 2007 . The government addressed this deficiency by creating The Research Council (established in 2005 by royal decree) to promote research and innovation on environmental protection, green building and eco-design (BTI, 2012). Oman's Green Building Council (GBC), newly established in 2012, is a non-profit non-governmental organization established with the objective of promoting green building concept and its principles, protect the environment and ensuring sustainable development and has been actively promoting green concept through conferences and seminars. Oman has 15 projects registered with LEED (Leadership in Energy \& Environmental Design, USA) (Senerivatne, 2010). Some of the projects in Oman pushing for LEED certification are Muscat International Airport, Oman Botanic Garden, The Jebel Al Akhdar Hotel, Salalah International Airport, The Oberoi Resort at Bander Al Khiran, The Novotel Hotel in Muttrah, The Ibis Hotel in Sohar and Oman Convention and Exhibition Centre.

\section{Pursuing Green Construction}

Construction practitioners worldwide are beginning to appreciate sustainability and acknowledge the advantages of building sustainably. Sustainable buildings would contribute positively to better quality of life, work efficiency and healthy work environment. The approach of sustainable construction will enable construction practitioners to be more responsible towards the need for environmental protection without neglecting the social and economic aspects in the quest for balanced outcomes. The right motivation will push the industry to enter into green construction.

There are many factors that can influence the decision to pursue green construction. Nurul Diyana and Zainul Abidin (2013) have grouped such factors into financial, ethical and business strategies. Du Plessis (2007) highlighted that awareness and knowledge are crucial to start any green action. Therefore, awareness and knowledge is included as the $4^{\text {th }}$ factor, and are further divided into categories as shown in Table 1, which is elaborated next. The purpose of all business strategies is to ensure how a business can persistently create more value (Aye, Bamford, Charters \& Robinson, 1999). While the main focus on green building is its positive impact to the environment, research shows that a developer's decision to go green remains rooted in its financial viability (Robichand \& Anantatmula, 2011). The green building costs can actually be lower than conventional method and saves energy as demonstrated by Hydes and Creech (2000). These buildings achieve superior long term performance making them attractive investments for facility owners and developers in both public and commercial sectors (Lapinski, Horman \& Riley, 2006). Some of the economic benefits of green building are savings in capital and operational costs, improved marketability and heightened public profile (Urbecon Bulletin, 2008).

The benefits of green buildings for the Middle East are not only environmentally-related, but extend to economic and social aspects. Lower long term operating costs can be achieved via reduced energy consumption, reduced emissions, improved water conservation, temperature moderation and reduced waste (Katkhuda, 2013). Other benefits associated with green building for the occupiers include gains in employee productivity, reduced absenteeism and building-related health problems leading to reduction in health and safety costs, improved morale and better employee retention (Pearce, 2008). There is a strong positive correlation between work performance of employees and the building in which the process takes place. Studies have proven that the increase in productivity gains is related to the improvements of the indoor environments (Ries, Bilec, Gokhan \& Needy, 2006).

One of the essential and effective driving forces in promoting green building is financial support from the government. To meet these objectives, each country has its own concern and establishes the corresponding policy and instruments for the building industry (Chan, Qian \& Lam, 2009). Regulations and rules ensure a minimum standard of quality is maintained. Most government offers monetary incentives to attract green construction (Hakkinen \& Belloni, 2011). Financial incentives including tax credits/abatement, fee reduction/waiver, grants and revolving loan funds are highly successful means of encouraging developers to adopt green building practices (US Green Building Council [USGBC], 2011).

\section{Field Study}

This research is exploratory in nature, which is used optimally for situations which will increase understanding and expand knowledge that has had little research (Cresswell, 2003). In Oman, the concept of green construction is relatively new. With an almost non-existent research culture in the industry (BTI, 2013), it is unknown how far this concept has penetrated the local construction industry. According to Zainul Abidin (2010), to ensure that 
green concept can progress further in the industry, it is vital to understand the current knowledge, acceptance and barriers to instigate further actions for effective implementation. A survey was thus conducted to investigate the current progress of green construction in Oman from the view of its practitioners. Apart from general demographic questions, the structured questionnaire used in the survey was prepared focusing on 2 main sections: motivation factors and expectations on future prospects. The questionnaires were first distributed via post and emailed to various construction stakeholders such as developers, contractors, consultants (such as engineers and architects), as recommended by Zainul Abidin (2010) to understand current practices of the building industry. However, due to very poor response, a snowball sampling style is later adopted to gain more response as it enabled prior interactions with respondents. A total of 200 questionnaires were distributed and 67 responses (33\%) were obtained for analysis. A sample size of 20 to 30 is deemed adequate to enable internal generalization in exploratory studies (Leech, 2005). Low response rates are considered typical in studies involving construction practitioners (Dulaimi, Ling \& Ofori, 2004). The data gathered was analysed qualitatively (open-ended questions) and quantitatively (scale-typed questions). Majority of the respondents were from contracting companies $(47.8 \%)$, followed by developers (17.9\%), engineering consultants $(16.4 \%)$, university and government sectors $(16.4 \%)$ and lastly architectural firms (1.5\%). A total of 50.8\% respondents have more than 10 years of experience working in the construction industry and another $32.8 \%$ have work experience of between 5 to 10 years. Their range of project profiles varied from individual villas to commercial buildings, governmental offices and infrastructures projects.

\subsection{Results and Discussion}

\subsubsection{Motivating Factors for Green Construction}

A total of 13 motivating factors have been identified as potential reasons to encourage acceptance and implementation of green construction. These factors are grouped into 4 categories: financial, knowledge and awareness, business strategy and ethical. Each category has between 2 or 3 sub-factors. The factors were rated using Likert scale between 'very low' (1) to 'very high' (5). Further support to these findings was available through open-ended questions to enable the respondents to express their opinion on the subject matter. The results from the survey are summarized in Table 1.

Table 1. Motivating factors for green construction in Oman

\begin{tabular}{lcc}
\hline Motivating Factors & $\begin{array}{c}\text { Average } \\
\text { Mean }\end{array}$ & Rank \\
\hline Financial & $\mathbf{3 . 4 9}$ & $\mathbf{2}$ \\
Green building can get more profit & 3.51 & 8 \\
There are many incentive by the government to encourage green building & 3.36 & 10 \\
The potential of saving money during operational of the building in the long term & 3.60 & 5 \\
Knowledge and Awareness & $\mathbf{3 . 3 1}$ & $\mathbf{4}$ \\
More developers / contractors / builders are aware and interested about green & 2.97 & 13 \\
construction & & \\
The government supports the construction of green building & 3.57 & 7 \\
The increase of knowledge on green building among construction practitioners & 3.40 & 9 \\
Business Strategy & $\mathbf{3 . 4 3}$ & $\mathbf{3}$ \\
It is good for company's image & 3.64 & 4 \\
Venturing into green building ensure more opportunities in the future & 3.58 & 6 \\
Green construction will become a trend in Oman & 3.27 & 11 \\
There is good market for green building in Oman & 3.24 & 12 \\
Ethical & $\mathbf{3 . 7 7}$ & $\mathbf{1}$ \\
It is good way to protect the environment & 3.97 & 1 \\
Green building shows that the company cares for the society and environment & 3.67 & 2 \\
Green building is a safe way to avoid infringement of laws and regulations & 3.66 & 3 \\
\hline
\end{tabular}


Based on Table 1, the top driving factor to pursue green construction in Oman is related to ethical factors with all three sub-factors being in the top 3: 'to protect the environment' (3.97), 'company cares for society and environment' (3.67), and 'safe way to avoid infringement of laws and regulation (3.66). These findings support the study by Kibert (2007) who highlighted that green construction provides the solution in avoiding harmful activity towards the environment as it is premised on ecologically sound principles and comprehensively addresses the ecological, social and economic issues of a building in the context of its community. It is also perceived as a safe way to avoid legal related issues as it mainly covers environmentally-related considerations. Financial factors are second (3.49), with the sub-factors in this category obtaining $5^{\text {th }}, 8^{\text {th }}$ and $10^{\text {th }}$ place. The respondents acknowledged the potential monetary savings in the long run and the obvious profit potential. However, they generally disagree on government incentivisation that can support them financially. According to Zainul Abidin, Yusof \& Othman (2013), government is one of the main institutions that have a major influence over the development of any industry. Majdalani, Ajam and Mezher (2006) further stated that changes imposed by the government will bring about behavioral shift in the construction sector because the government is a regulator, major customer and industry sponsor.

With regards to 'Business Strategy', the 4 sub-factors can be seen in two perspectives. The respondents perceived that green construction is good for company image (ranked no.4) and venturing into green building will ensure more opportunities in the future (ranked no.5). This is supported in Nurul Diyana and Zainul Abidin's work (2013), who stated that implementing green construction would enhance the construction companies' public image and competitiveness in the industry. However, the other two factors are placed within the lowest 3 average mean: 'green construction will become a trend in Oman' (ranked no. 11) and 'there is good market for green building in Oman' (ranked no.11). Although respondents agreed that green construction can enhance their image and competitiveness, they perceived that the market and trend for green building in Oman is lucrative which paradoxically may deter their interest to pursue green. The demand for green construction depends on society's attitude towards the impact on the environment (Chan et al., 2009). In Oman, there is no 'sense of urgency' for green construction as they continue to enjoy cheap energy. As such, the lack of demand from the local market is clearly reflected in the relatively modest interest among construction practitioners towards developing in a green manner. 'Knowledge and awareness' falls into the last category with average mean of 3.31. The support from the government arising from their awareness on the green concept is placed at no. 7 followed by knowledge among the construction practitioners at no. 9. Finally, the respondents have ranked 'more developers / contractors / builders are aware and interested about green construction' as the last place. This is contrary to the findings of many scholars who have highlighted the importance of knowledge and awareness as the stepping stone to a wider green implementation (Zainul Abidin, 2010; Zhang, Shen \& Wu, 2011; Du Plessis, 2007). According to Zainul Abidin (2010), as construction practitioners, their awareness and knowledge would be important in creating a sustainable industry as they are the ones initiating, constructing and building the projects.

Some additional driving factors to pursue green construction provided by the respondents are to reduce energy usage, to encourage green city in Oman, to use safer materials, aesthetical benefit and to be at par with other MENA countries. In general, the highest average mean is 3.97 and the lowest is 2.97 . The study shows that the driving factors are within 'moderate' levels except for the lowest factor which fell within the 'low' category. This indicates that overall, any present actions to push green construction concept in Oman may not as yet have significant impact to the industry, as the driving forces which should stimulate green growth are still considered at the low-moderate level.

\subsubsection{Future Prospect for Green Construction}

The respondents were also asked about their perception on the future outlook of green application in the industry and why such opinions were given. It was revealed that the majority of survey respondents (37\%) perceived that changes will maintain at a moderate level, $34 \%$ respondents perceived it to be good while $25 \%$ perceived that the prospect is poor. This is illustrated in Figure 1.

The respondents who supported the positive outlook perceived that the government is only beginning to take interest on this issue, which should bring positive changes in the near future. A few government bodies and private companies have collaborated to build new buildings by using sustainable design techniques. It is believed that the government will introduce incentives and subsidies in the near future especially to promote windmill and solar-based systems. Already, there are a few new prototypes of green buildings in the region such as Eco house project. Further, the interest on green within MENA region also will push Oman to follow their green development. Working closely with Oman Green Building Council, the authorities are keen on establishing an Oman green building code. One respondent also stated that the government is coming forward and introducing laws to use locally manufactured products in its project, with the consultants given instructions to use natural 
resources. Although this is not widely practiced now, it will most likely improve in the future. One of the current barriers to such practices is knowledge and awareness. The respondents agreed that presently, awareness on this concept is very poor. Once awareness is raised, the concept will slowly but surely be applied to the projects.

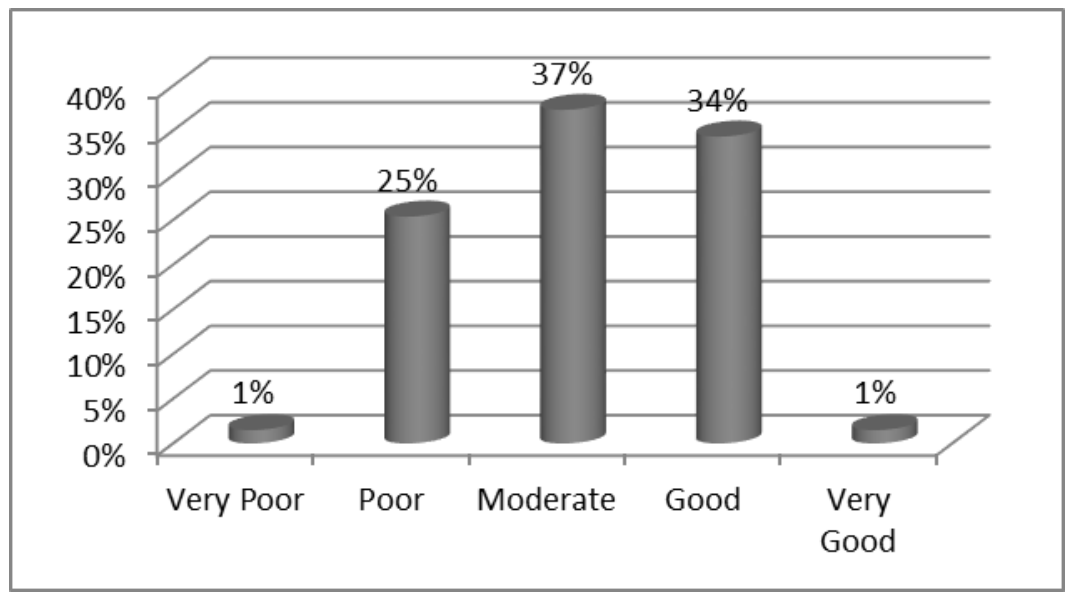

Figure 1.5-Year future prospect for green construction in Oman

The respondents who believed that the progress will either be 'moderate' or 'poor' stated the following issues: the majority of construction practitioners in Oman are still unfamiliar with green concept, and it will take time for things to change to green direction. With the lack of demand, many are not interested to know or get involved with green-related initiatives. The respondents also stated that currently, the green trend is not there yet. Only a handful of developers or builders talk about green and focus was only for large projects. Oman consists of many small and medium sized projects which persist on their own conventional way. Changes to the industry will only be visible if more projects regardless of sizes are on board with this concept. One respondent stated that the government bodies themselves do not fully comprehend green building issues. Thus, initiatives for green buildings are not full-scaled, with the Omani market still confined to local standards and practices. There is not much global impact in Oman to promote business in the country which can provide the desired payback to the developers / investors to strive for green building designs. One respondent stated that although there is a general acceptance of the importance of green in Oman, enforcement steps are not in place yet.

One respondent proposed that the prospect of this concept in Oman leaning towards the positive side or remaining status quo depended on the collective efforts of engineers, architects, planners in association with the policy makers and environmental leaders. He stated that the construction practitioners should look beyond their own locality, be innovative, seek a balanced solution, engage various stakeholders, adopt a holistic approach and give sustainability the benefit of any doubt.

\subsubsection{Recommendation to Promote Green Construction}

Recommendations to encourage green construction in Oman can be discussed in 3 categories: governmental support/action, knowledge and awareness, and private and professional initiatives.

Many respondents highlighted the actions that can be undertaken by the government and governmental agencies. First of all, the aspects related to environmental protection and green concept should be made compulsory at Municipal level. For example, every new construction must be mandated to provide green belts or plantation areas. The current municipality building regulations do not stress on green design and green practices. The respondents recommended that modifications to the present regulations are necessary to enforce better green requirements for all new projects. A few respondents also stated that the government has not encouraged the builders to pursue green building concept and any effort from the government side, if at all, was not widely known to many practitioners. As one of the industry's major client, government needs to show commitment and interest on this approach. Government itself should go green to encourage others to do so and backed by law and regulations can effectively operationalise and ensure wider implementation of green aspects. Various government measures related to tax-breaks and other benefits can be used as incentivisation for building green.

Recommendations have also been made to improve knowledge and awareness. According to the respondents, majority of practitioners in Oman have no or little knowledge on green building and its advantages. The best step to promote green construction is to reach the people through media, advertisement, seminars and trainings. 
Education can start early either from school or higher education level. Oman's Research Council has begun addressing the deficiency of research and development. This Council could spearhead more awareness programs and seminars to educate construction practitioners. Collaborations should be made with local Colleges and Universities to initiate interest among students. Networking and business linkages between local and foreign companies should be encouraged as it promotes knowledge transfer between foreign companies and local practitioners.

For private and professional initiatives, it is proposed that green-related conditions on the construction contracts are added by the clients and the consultants to ensure implementation. However, as this will involve policies and the law, a further detailed study is necessary before such conditions can be added in the contract. Research and development should also be encouraged to promote local green products. Due to lack of expertise locally, the government, with participation from construction companies, should bring in foreign expertise to work together in realizing this green concept in new projects and at the same time provide learning opportunities to local engineers, architects and contractors to gain experience and be exposed to this new concept. Accessibility to prototypes of green buildings is another way to improve knowledge and spark interest. Design-wise, green features and green technologies should be effectively encouraged, for example, the use of solar and wind power for electricity, use of recycled materials, use of good quality insulating windows etc.

\section{Conclusion}

The push towards green construction is relatively new in Oman, but actions have been initiated to bring this concept to the forefront of the country's development agenda to be at par with other developing countries. As Oman still enjoys cheap fuel and the negative impacts arising from unsustainable construction is not yet apparent as compared to many developed and fast developing countries, the need to go for green construction may not be seen as crucial. In MENA region, Oman is lagging behind U.A.E., Qatar and Saudi Arabia in green construction achievements. According to Seneviratne (2010), Oman is ranked $4^{\text {th }}$ in the number of LEED registered projects, below the 3 countries mentioned before. In a nutshell, the progress of green construction is still in its infancy. The Research Council has begun taking some steps to promote environmental awareness and Oman Green Building Council has been launched to spearhead the country's green agenda. An overview study is conducted to understand the current status including factors that can drive construction practitioners to pursue green construction and how they foresee the progress in the next 5 years based on current experiences. Zainul Abidin (2010) stated that understanding the current status will provide the platform for further improvement. The motivating factors to push forward this green concept into new construction projects have been identified and categorized into 4: finance, knowledge and awareness, business strategy and ethics. It was discovered that factors relating to ethical issues received the highest average mean while factors on knowledge and awareness are the lowest. The low-moderate findings across the driving factors indicate that any actions to push green construction concept in Oman may not have significant impact to the industry as yet. The respondents from the survey have divided views on the future outlook of green construction in the country, with some seeing as promising while others being not so optimistic. In general, those who perceived the progress positively commented that the collaboration and actions taken by the government and private organizations will inevitably propel the construction industry towards wider green application. Obversely, the reasons are mainly attributable to poor knowledge of local construction practitioners and the perceived lack of demand. The recommendations put forth on how to encourage better green are divided into 3 categories: governmental support/action, knowledge and awareness, and private and professional initiatives. Although the construction industry in Oman has made various efforts for the implementation of green construction, the practitioners from this study still perceived that more effort is necessary. The suggestions given can be the basis for future research and action to push the standard of green construction to be at par or even at higher achievement levels than its neighbours.

\section{Acknowledgments}

The authors acknowledge the financial support provided by Universiti Sains Malaysia (USM) and appreciate the cooperation provided by Muscat College, Sultanate of Oman throughout the duration of this research.

\section{References}

Al Hathloul, S. (2004). Planning in the Middle East: moving toward the future. Habitat International, 28, 641-643. http://dx.doi.org/10.1016/j.habitatint.2004.04.004

Al Saleh, Y. M. \& Taleb, H. M. (2010). The integration of sustainability within value management practices: A study of experienced value managers in the GCC Countries. Project Management Journal, 41(2), 50-59. http://dx.doi.org/10.1002/pmj.20147 
Al-Badi, A. H., Malik, A., \& Gastli, A. (2011). Sustainable energy usage in Oman - opportunities and barriers. Renewable and Sustainable Energy Reviews, 15, 3780-3788. http://dx.doi.org/10.1016/j.rser.2011.06.007

Albawaba Business. (2012). Oman: Government spending in construction industry to jump 23\%. Retrieved January 31, 2012, from http://www.albawaba.com/govt-spending-construction-industry-jump-23-10b-411055

Alnaser, N. W., \& Flanagan, R. (2007). The need of sustainable building construction in the Kingdom of Bahrain. Building and Environment, 42(1), 495-506. http://dx.doi.org/10.1016/j.buildenv.2005.08.032

Authority for Electricity Regulation. (2011). Annual Report 2011: Oman. Retrieved from http://www.aer-oman.org

Aye, L., Bamford, N., Charters, B., \& Robinson, J. (1999). Environmentally sustainable development: a life cycle costing approach for a commercial office building in Melbourne, Australia: Proceedings of the 15th Annual ARCOM (Association of Researchers in Construction Management) Conference (pp. 735-742). Liverpool, United Kingdom.

Bertelsmann Transformation Index (BTI). (2012). Oman Country report. Retrieved from http://www.bti-project.de/fileadmin/Inhalte/reports/2012/pdf/BT\%202012\%20Oman.pdf

Business Monitor International. (2013). Oman infrastructure report Q2 2013. Retrieved from http://www://fastmr.com/prod/584538_oman_infrastructure_report_q2_2013.aspx

Carbon Dioxide Information Analysis Centre. (2007). Ranking of the World's countries by 2020: total CO2 emission. Retrieved from http://www.cdiac.ornl.gov

Chan, E. H. W., Qian, Q. K., \& Lam, P. T. I. (2009). The market for green building in developed Asian cities the perspectives of building designers. Energy Policy, 37(8), 3061-3070. http://dx.doi.org/10.1016/j.enpol.2009.03.057

Creswell, J. W. (2003). Research Design: Qualitative, Quantitative and Mixed Methods Approaches (2nd ed.). Thousand Oaks, California: SAGE Publications.

Du Plessis, C. (2007). A Strategic Framework for Sustainable Construction in Developing Countries. Construction Management and Economics, 25(1), 67-76. http://dx.doi.org/10.1080/01446190600601313

Dulaimi, M. F., Ling, F. Y. Y., \& Ofori, G. (2004). Engines for change in Singapore's construction industry: An industry view of Singapore's construction 21 report. Building and Environment, 39(6), 699-711. http://dx.doi.org/10.1016/j.buildenv.2004.01.011

Häkkinen, T., \& Belloni, K. (2011). Barriers and drivers for sustainable building. Building Research and Information, 39(3), 239-255. http://dx.doi.org/10.1080/09613218.2011.561948

Hydes, K., \& Creech, L. (2000). Reducing mechanical equipment cost: the economics of green design. Building Research and Information, 28(5/6), 403-407. http://dx.doi.org/10.1080/096132100418555

Katkhuda, N. (2013). Green buildings and the Middle East. EcoMENA. Retrieved from http://www.ecomena.org

Lapinski, A. R., Horman, M. J., \& Riley, D. R. (2006). Lean Processes for Sustainable Project Delivery. Journal of Construction Engineering and Management, 132(10), 1083-1091. http://dx.doi.org/10.1061/(ASCE)0733-9364(2006)132:10(1083)

Leech, N. (2005). The Role of Sampling in Qualitative Research. Academic Exchange Quarterly. Retrieved from http://www.thefreelibrary.com/The+role+of+sampling+in+qualitative+research.-a0138703704

Ling, F. Y. Y., \& Gunawansa, A. (2011). Strategies for potential owners in Singapore to own environmentally sustainable homes. Engineering, Construction and Architectural Management, 18(6), 579-594. http://dx.doi.org/10.1108/09699981111180890

Majdalani, Z., Ajam, M., \& Mezher, T. (2006). Sustainability in the construction industry: A Lebanese case study. Construction Innovation, 6, 33-46. http://dx.doi.org/10.1108/14714170610710613

Nebel, S. (2013). Towards sustainable patterns of urbanization in Oman. Retrieved from http://www.gutech.edu.om

Nurul Diyana, M. A., \& Zainul Abidin, N. (2013). Motivation and expectation of developers on green construction: A conceptual view. Proceeding of World of Science, Engineering and Technology, International Conference of Housing and Urban Environments (pp. 100-104). Venice, Italy. 
Oxford Business Group. (2012). The Report: Oman 2012. Retrieved from http://www.oxfordbusinessgroup.com/country/oman

Pearce, A. R. (2008). Sustainable capital projects: leapfrogging the first cost barrier. Civil Engineering and Environmental System, 25(4), 291-300. http://dx.doi.org/10.1080/10286600802002973

Ries, R. M., Bilec, M. M., Gokhan, N. M., \& Needy, K. L. S. (2006). The economic benefits of green buildings: a comprehensive case study. The Engineering Economist, 51(3), 259-295. http://dx.doi.org/10.1080/00137910600865469

Robichand, L. B., \& Anantatmula, V. S. (2011). Greening project management practices for sustainable $\begin{array}{llll}\text { construction. Journal of } & \text { Management }\end{array}$ http://dx.doi.org/10.1061/(ASCE)ME.1943-5479.0000030

Senerivatne, M. (2010, October). Green buildings in the GCC Countries. Presented in Development of Economic and Innovation, Montreal, Canada. [Powerpoint slide]. Retrieved from qc.cme-mec.ca/download.php?file=gfqun0gk.pdf

The Research Council. (2013). Oman eco house design competition. Retrieved from http://home.trc.gov.om/tabid/402/language/en-US/Default.aspx

United Nation Development Programme [UNDP]. (2010). Five Arab States among top leaders in long-term development gains. Human Development Reports 2010. Retrieved from http://www.hdr.undp.org/en/mediacentre/news/announcements/title,21573,en.html

Urbecon Bulletin. (2008). Building green: financial costs and benefits. SGS economic and planning. Retrieved from http://www.sgsep.com.au/system/files/Urbecon_Aug\%2008(Web).pdf

US Green Building Council [USGBC]. (2011). Green building incentives strategy. Retrieved from http://www.usgbc.org/DisplayPage.aspx?CMSPageID=2078

Zainul Abidin, N. (2010). Investigating the awareness and application of sustainable construction concept by Malaysian developers. Habitat International, 34(4), 421-426. http://dx.doi.org/10.1016/j.habitatint.2009.11.011

Zainul Abidin, N., \& Powmya, A. (2013). Green Construction in Oman: Progress and Implementation Barriers: Proceedings of the 2013 Sustainable Building Conference. Dubai, U.A.E.

Zainul Abidin, N., Yusof, N., \& Othman, A. A. E. (2013). Enablers and challenges of a sustainable housing industry in Malaysia. Construction Innovation, 13(1), 10-25. http://dx.doi.org/10.1108/14714171311296039

Zhang, X. L., Shen, L. Y., \& Wu, Y. Z. (2011). Green strategy for gaining competitive advantage in housing development: A China study. Journal of Cleaner Production, 19, 157-167. http://dx.doi.org/10.1016/j.jclepro.2010.08.005

\section{Copyrights}

Copyright for this article is retained by the author(s), with first publication rights granted to the journal.

This is an open-access article distributed under the terms and conditions of the Creative Commons Attribution license (http://creativecommons.org/licenses/by/3.0/). 